V. Filipchuk, Cand. Sc. (Publ. Admin.), orcid.org/0000-0002-7335-2256, G. Malkina, Dr. Sc. (Polit.), Assoc. Prof., orcid.org/0000-0002-2307-4702,

V. Kolyukh, Dr. Sc. (Polit.), Assoc. Prof., orcid.org/0000-0002-8545-7450,

I. Petrenko, Dr. Sc. (Polit.), Assoc. Prof., orcid.org/0000-0003-3328-4102
Taras Shevchenko National University of Kyiv, Kyiv, Ukraine, e-mail: v.filipchuk@icps.com.ua

\title{
GOVERNANCE MODELS IN THE GLOBALIZATION ERA: FROM MORAL TO POLITICAL RESPONSIBILITY
}

Purpose. To study the role and significance of the moral responsibility of international management in governance models under conditions of global economy and democracy.

Methodology. The authors use structural-functional, institutional, and comparative methods as well as the methods of synthesis and analysis.

Findings. The authors examined and proved the key statement of the study. Modern international management is a holistic corporate governance culture. The foundations of leadership and professional qualities of modern international management are their moral qualities. In democratic governance models, the moral qualities of management turn into political responsibility and ensure the quality of management, the growth of state capacity of Ukraine, the formation and promotion of national interests in the face of global threats and challenges.

Originality. The authors prove that the main determining actor in the governance model is international management characterized by stable moral qualities. Only in this case, a governance model will achieve the highest efficiency and ensure the growth of state capacity, as well as the promotion of national interests in the face of global threats and challenges.

Practical value. The results of the study can be used to improve the legislative framework as well as to develop the educational programs for international management education. The experience of international management education under consideration, as well as the use of moral responsibility in the behaviour patterns of international management, will ensure the quality of governance, the growth of Ukrainian state capacity and the promotion of national interests in the global economy and democracy.

Keywords: international management, governance models, moral responsibility, national interests, state capacity, global economy, global democracy

Introduction. Currently, Ukraine is going through a difficult path of formation and development of government authorities: the Verkhovna Rada, government, presidency, the court system, as well as local government and self-government entities. The main problem is the choice of the most effective governance model in the state, which would: a) comply with the principles of democracy; b) ensure integration of the Ukrainian economy into the economic system of the European Union and the world economy as a whole; c) correspond to the sociocultural traditions prevailing in the history of the development of Ukrainian society.

The choice of the governance model is complicated by several reasons:

a) there are at least five democratic governance models in a global economy and democracy that are significantly different from each other;

b) the global economy model has been formed. Despite the fact that continuous changes occur in it, its key characteristics remain stable. To become a key actor in the current model of the global economy, it is necessary to learn how to be competitive;

c) the history of the development of Ukrainian society has the traditions associated with opposing and incompatible models of managing the economy and the state.

In addition, the problem of choosing a governance model is exacerbated by globalization. On the one hand, globalization strengthens social, political and economic relations due to technological changes and the flow of people, resources and ideas across state borders. On the other hand, it makes the choice of a governance model dependent on external factors: investors, foundations and grant organizations, international financial and political organizations, and others. External lobbying of corporate interests often turns out to be stronger than the need to uphold national interests.

(C) Filipchuk V., Malkina G., Kolyukh V., Petrenko I., 2020
In this situation, the moral and political responsibilities of the Ukrainian political elite for choosing an economic and political course of Ukraine's development as well as the conformity of their individual skills and leadership competencies to modern behaviour patterns in international business and international management are of paramount importance.

In the eighth edition of the popular book International Management Behavior: Global and Sustainable Leadership, the authors reveal the features of the formation of modern and future world leaders. Due to professional competencies, business practices and moral qualities, modern international management ensures the sustainable development of all areas of society at all levels: from regional to global [1]. The authors reveal the latest developments in world business practice, on the basis of which they propose the concept of informed global leadership as an integrating basis for implementing a global strategy. From the concept proposed by Lane H. and Maznevski M., the two ideas are important for our research:

1. Modern international management is seen as a holistic corporate management culture that effectively displays its leadership and professional qualities in any field of activity: in economy, politics, social sphere, as well as at all levels - regional, national and global.

2. Moral qualities are the foundation of leadership and professional qualities of modern international management. That is why the formation of international management behaviour begins with the formation of moral qualities [2]. The moral qualities of international management play a key role in all governance models.

In this article, the authors will prove the importance of the moral responsibility of international management for choosing a governance model and its effectiveness in a global economy and global democracy.

Results. Currently, a significant number of researchers, politicians and the public, including those from countries with the transformational economy, believe that liberal prin- 
ciples of governance have failed to ensure a decent standard of living for citizens. An open economy, regularly re-elected parliament, government and president, respect for human rights, as well as the influence of civil society on the nation's life sustenance, - all these are not enough to effectively manage the economy and the nation in the context of globalization. Critics claim that liberal governance and the order that it establishes at the regional, national and global levels do not solve the problems of cultural identity, equitable distribution of material resources, understanding the unity of the Earth's ecosystem, the formation of common values and morals [3].

The stunning effect was provoked by the fact that over the past four years the number of people lacking food and dwelling has been growing not only in low-income countries, but also in highly developed countries such as Germany, the USA, France, and others. Until recently, human migration was determined by their desire to become the elements of a behavioural model with liberal management principles, which guaranteed equal rights and freedoms of citizens. However, in fact, it turned out that obtaining citizenship of Germany, France or another country from the international club G7 or G20, no longer means social security and the necessary level of social benefits. It was found that the current global economic system and its government entities were essentially created and regulated by less than $1 \%$ of the population owning more than $47 \%$ of the total wealth of the world [4].

For example, in 2011 in the USA, the Institute for Political Studies created a special website Inequality.org, on which the information on economic and social inequality in the USA is updated weekly [5]. The site is available for research, historical references, comments, etc. on the topic of inequality. The above figure shows the results of the study by the American economist Saez E. (Figure). Saez proved that in 2018, the incomes of $10 \%$ of the most successful Americans were 9 times higher than the incomes of another $90 \%$ of the US population. The income of $1 \%$ of Americans exceeded the income of $90 \%$ of US residents by more than 39 times. $0.1 \%$ of the Americans had more than 196-fold income [5].

Currently, international economic institutions, such as the World Bank, the World Trade Organization (WTO), the International Monetary Fund (IMF), the Organization for Economic Co-operation and Development (OECD), which since 2000 have been the fundamental organizations of the global economy, are openly criticized and are losing their influence. Mass protests swept around the world, such as:

1. "Occupy Wall Street" (2011 New York, USA). The movement was held under the slogan "We are the $99 \%$ " and was directed against social and economic inequality in the USA, excessive influence of corporations on the government, especially in the financial services sector, and others.

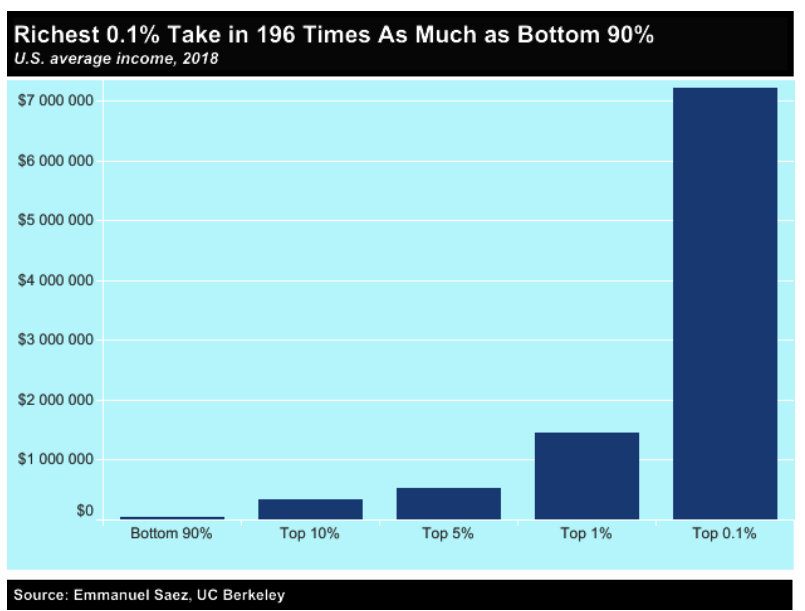

Fig. Household income ratio of the Americans in 2018 [5]
2. The anti-austerity movement in Spain (2011-2015), which was attended by more than 6.5 million Spaniards. The movement was caused by high unemployment and economic inequality. It was directed against large banks and financial groups, as well as the political system that was favouring them.

3. Nuit Debout in France (2016), which was supported by more than $60 \%$ of the population of France. The protest movement was directed against the policy of the government entities, which tried solving the economic problems of the state at the expense of the population.

Since 2013, China's “One Belt - One Way” initiative, which is gaining strength every year, has been confronting the liberal governance model. Currently, it unites 76 states of the world and is constantly expanding [6]. The China Initiative promotes a state-owned model of governance with developed market relations. China promotes the idea that this model of managing the economy and the nation most effectively protects national interests, and also provides greater social security and the nation's living standards [7].

In 2014, Ukraine ratified the "Ukraine-European Union Association Agreement" [8]. This meant that Ukraine consolidated its commitment to the values of democracy at the legislative level. The choice was made in favour of the liberal management model.

In practice, the implementation of the chosen economic and political course faced a major problem. The member states of the European Union have different models of managing the economy and democracy. These models are closely related to the national and cultural traditions of nations, which reduces the likelihood of their use and adaptation in Ukrainian statehood as the dominant governance model.

Governance models that are used in the European Union member states are competing with each other and are not entirely perfect. The connection of these governance models with historical and cultural traditions, on the one hand, allows these models to be quite effective across the national economy and uphold national interests in global processes. On the other hand, this relationship reduces the effectiveness of these governance models in the states with other sociocultural traditions. In fact, these governance models are not interchangeable and complementary. They are effective in the unity of communication: historical and cultural traditions - the state education system - the accumulated experience of international relations.

In general, at present, the majority of the European Union member states support and develop liberal governance ideas that are promoted by the United States, as well as the United Kingdom, Germany and France. However, there are some nations (e.g., Hungary, Italy, Romania, Poland, and so on), which are getting inclined towards the ideas of governance promoted by China, whose economic development is not much inferior to the US economy. The international management of these nations is beginning to tilt toward the active participation of the state in economic management models.

Thus, the ratification of the "Ukraine-European Union Association Agreement" by Ukraine, in fact, threw the international management representing Ukraine into a dilemma of selecting a model of global economy and global democracy with a whole range of governance models, government institutions and international management behaviour patterns.

We will briefly consider the features of the basic democratic governance models and the features of their representation at the national and global levels. Given different approaches and, accordingly, the diversity of the proposed models, we will consider the models proposed by Kuyper J. as a basis; however, we will clarify them according to our understanding [9].

1. Model of Intergovernmental Democratic States. This model provides for the management of an elected government that defends national interests and represents them overseas. The model of intergovernmental democratic states has a long 
history and has had a significant impact on the governance of the global economy and democracy. Its main disadvantages are as follows: a) at present, democratic states make up no more than $50 \%$ of the world countries; b) representatives of national governments in intergovernmental relations do not always defend national interests and cannot uphold national interests due to objective and subjective factors.

Fuchs T. considers the strengths and weaknesses of this governance model using the modern challenges of Cyber Development as an example [10]. Fuchs argues that governments of member states of the European Union have varying degrees of influence in the intergovernmental institutions of the European Union: the European Parliament, the European Council, the European Commission, the European Accounts Chamber, the European Central Bank, and so on. The governments (international management) of those nations that have lower potential for participation in cyber development fall into a certain dependence on the governments of the nations with higher potential. Through complex compromises, certain agreements can be reached. However, these agreements often result in forced fading of national interests into insignificance.

A similar problem manifests itself in the joint development of other high-tech products that require sources of long-term financing and highly qualified personnel. For example, in course of the development and practical implementation of artificial intelligence products [11], or in course of partnerships in the space industry [12]. The above studies prove that in this governance model, despite the feasible liberal context, the inequality precedent is initially laid. International management uses the economic and scientific potential of its nations to create a certain kind of monopoly through which they influence the behaviour of the international management of other states that do not have such a high potential.

2. Model of Cosmopolitan Democracy. Cosmopolitan governance involves the use of the norms and values of democracy at all levels, from local to global. This governance model provides for a closer participation of the people in government at the national level, as well as its representation at the international level. The model proved its effectiveness at the end of the twentieth century. However, the evidence shows that with an increase in the scale of its use, the management efficiency proposed in the model decreases. Wu G., examining the institutional features of the global economy and the way it revises the movement of capital, labour and consumption, discovered a new network of relationships in which capital depends on effective authoritarianism, while democracy depends on capital. $\mathrm{Wu}$ argues that the emerging link between state markets has fundamentally changed existing institutional systems, damaging the values of democracy [13]. Thus, broad people's participation in governance appears to be justified and effective in terms of upholding national interests. However, at the global level, this governance model shows low efficiency. It turned out that the priority of national interests at the global level eventually and in long-term forecasting would harm national interests. For example, Poland, in 2018 defending its views on constitutional and legal reform, was on the verge of being imposed European economic sanctions.

3. World Government. This governance model involves the creation of a centralized and federal global system. The model assumes the equal right to vote for each person with an equitable distribution of material resources, as well as the direct election of a global parliament, authorized courts and a single global constitution, which sets out the basic rights and obligations of all citizens. This governance model provides for the creation of the executive authority or world government, which will have the power to overcome global problems such as war, climate change, environmental disasters, etc. Elements of this governance model are created and operate on a civilization scale. For example, the United Nations (UN), the Organization for Security and Cooperation in Europe (OSCE), International Police Organization (INTERPOL), etc. How- ever, this model is more reminiscent of the world governance model of the most developed states. Critics of the model cite an example of veto power of the United States, China, Russia, France, and the United Kingdom in the UN Security Council as the main argument. According to critics, the position of these states undermines any democratic initiative that is not in the interests of any of them.

On the other hand, Zaring D. gives the following counterargument [14]. For a long time, national governments were powerless against the influence of large banks, which, if desired, could not only destroy national economies, but also harm the global economy. To counter global capital, regulatory authorities were created at the level of intergovernmental relations. These entities have developed the programs for small banks, insurers, brokers, dealers and other enterprises that are most exposed in times of crisis. The confrontation with large banks began at the level of informal political meetings and undemocratic decisions. However, at present, this initiative of national governments has evolved into an orderly and functioning regulatory environment. The international financial system largely works predictably and in a coordinated manner, and to a lesser extent depends on the policies of large banks and transnational corporations.

The given example of international financial regulation is indicative of the possibilities of this governance model. The international government is able to: a) achieve harmonization of any process through the establishment of common rules; $b$ ) establish cooperation to ensure compliance with the general rules; c) ensure the harmonization of the fundamental principles of the coexistence of national interests.

4. Deliberative Democracy. This governance model assumes that the effectiveness of any field of activity at all levels (from regional to global) in all formal and informal aspects can be achieved by compromising without coercion or by convincing argumentation. This approach provides the model with efficiency and democracy. Blau A. argues that deliberative democracy is much more convincing and effective than party democracy, which is currently accepted in all democracies [15]. This governance model is focused on the creation of certain influence groups to uphold national interests within the state and at the interstate level. The model provides an opportunity to hear reasoned objections of the injured party and give them the reasoned answers. It is possible to include non-state actors in the governance model and their impact on interstate relations and the representation of national interests at the global level.

Informal and non-governmental public organizations, youth groups, epistemological communities and business organizations gain access to global decision-making. For example, participation in IMF loan agreements, WTO negotiations, etc. An increase in key actors in the governance model increases the diversity of points of view and enhances the ability to challenge and reject unconvincing decisions. By making negotiations more consultative, economics and politics become more democratic and reasoned in their decisions.

5. Radical Democracy. The fundamental idea of this governance model is that national interests should not be built on the protection of capitalism, property rights and social classes' ideas about governance. These structures create systems of domination and alienation that must be overcome. Social movements must find new models of global governance based on cooperation, good neighbourliness and ecology. In the collective monograph "Building Global Democracy?", the authors argue that the scope, effectiveness, and legitimacy of the modern global governance model are far behind the needs. The authors substantiate their arguments with studies of thirteen world organizations, including the UN, G8, WTO, ICANN and IMF. The authors argue that all attempts by public organizations to influence the decisions of these organizations and become part of the management of these organizations were unsuccessful. These global governments do not accept civic 
initiatives and are not accountable to the public and states. They live in their own niche, pursuing narrow corporate interests at the global level [16]. That is why it is not necessary to try to reconstruct them, but to create new governance models, in which the values of a different format should become a priority: human values, natural ones, and those of the Universe.

The democratic economic governance models we have examined are not sustainable. In essence, they cannot be such, because each of the governance models is open. The openness of the model provides for pluralism of opinions as well as discussion and practice on improving its characteristics.

Each of the considered governance models has its own strengths and weaknesses. All models are subject to criticism and only partially are put into practice. However, Little A. and Macdonald K. claim that imperfect, but meaningful and promising democratic governance models and practices survive in extremely adverse conditions. Little and Macdonald prove their statement with examples of governance models at national and global levels [17].

Kuyper J. claims that instead of considering the above governance models as an idealized set of institutions that nations need to create in order to represent national interests at the global level, the fundamental principles should be developed on which these governance models will work [9]. Such principles are comparable to the values with common history and are embedded in culture and education. This may be exemplified by the values of building a society and a nation proposed by Plato. For several millennia, these values have formed the foundations of European culture and spirituality. They remain valid and efficient to this day [18].

Kuyper suggests using the following set of values as the basis of modern governance models: inclusiveness, equality, public control, transparency, responsibility, deliberation [9]. These values allow us: a) to fully ensure the representation of national minorities and their traditions at the national level; b) to represent and protect national interests in global processes.

Thus, we conclude that the choice of a governance model for Ukrainian international management in fact should not begin with the choice of a ready-made model and its adaptation to the Ukrainian mentality. It should begin with the definition and formation of values and moral qualities consistent with national culture and traditions. An established set of moral qualities will be a kind of matrix on the basis of which either a new governance model will be created or an already existent governance model will be selected and adapted.

We consider several key ideas from modern international practice that reveal the tendency to create new governance models, as well as the use of ready-made governance models and behaviour international management models. From our point of view, these ideas will allow, on the one hand, proving the importance of moral qualities and moral responsibility of the political elite for choosing a national governance model in the context of global economy and democracy. On the other hand, it is possible to attract the world governance experience into the Ukrainian system of education of international management and the formation of governance culture in Ukraine.

The first idea. In the formation of a managerial culture and in the selection of an effective governance model, the meaning of the term "state capacity" occupies an important place. The term reveals the ability of a government to collect taxes, maintain law and order and create public goods for its citizens. State capacity consists of two key components. Firstly, it is the nation's ability to establish rules and monitor their implementation on its territory (legal capacity). Secondly, it is the ability to collect tax revenues from the economy in the amount necessary to implement the declared state policy (budget potential).

Boettke P. and Candela R. argue that there is a cause-effect relationship between state capacity and economic development. This link is functional. Depending on the governance model and moral qualities of international management, it can both strengthen and weaken state capacity. Boettke and Can- dela proved this statement on the examples of privatization in Russia after the collapse of the Soviet Union, as well as the consequences of the political unification of Sicily with the Italian peninsula after the Napoleonic wars [19].

State capacity is formed by the institutional context, i.e. not only by the quality and effectiveness of the governance model that the national political elite or international state management has chosen and adheres to. The selected governance model should be consistent with national and cultural traditions. These are the traditions on the basis of which the state education system forms certain sets of moral values in the rising generations. These values determine the behaviour features of citizens and civil society, and are also decisive in the behaviour patterns of international management. They ensure the effectiveness of the selected governance model, which is determined by the growth/decrease of state capacity.

If national and cultural traditions, as well as values that are formed in society do not correspond to the chosen governance model, then any reform of the economy, even taking into account the introduction of the most effective governance models, will lead to the theft of state capacity and its degeneration. Moral qualities and values do not become political responsibility. They do not act as the main limiter of the opportunities that open up for international management in the chosen governance model. For this reason, as Boettke and Candela claim, in each of the examples of Russia and Italy that they examined, the political and economic transition, aimed at ensuring clearly defined and strictly observed property rights, reduced the state capacity of these nations instead of raising it [19].

A similar situation occurred in Ukraine. At first glance, the liberalization of the economy and politics in the first decades of Ukraine's independence had a clear focus on creating a liberal governance model based on freedom, restriction of state power, self-determination, people's power, and so on. International management, led by the Presidents of Ukraine Leonid Kravchuk and Leonid Kuchma, announced a management reform based on European values in order to achieve a European standard of living, the development of Ukrainian statehood and an authoritative representation of national interests in the global world.

However, as it turned out:

a) the selected "European" management system did not have clear safety mechanisms that would protect state capacity, as provided for in the governance models of all states of the European Union;

b) the reforms were carried out by international management, which did not have well-established moral qualities and turned out to be indifferent to national interests. The selected "European" governance model did not correspond to the moral values of Ukrainian management. In the chosen model, the moral qualities of management did not pass into political responsibility.

As a result, over 20 years of Ukraine's independence, the chosen "European" governance model has led to a significant reduction in state capacity, instead of its growth. At that time, as, for example, in Poland, Slovakia, Hungary and some other European countries, a similar management system with working restrictions only led to a significant increase in state capacity over this time period.

The second idea. An important condition for the effectiveness of any governance model is its openness to innovation. In one of the latest studies on this topic by Scholte, the following is stated. Democratic governance models are currently competing with various anti-liberal governance models that are based on [3]:

a) conservative nationalism (e.g., governance of Bolsonaro in Brazil, Modi in India, Putin in Russia, Erdogan in Turkey and Trump in the USA);

b) the unity of global orientation and sovereignty or a state model of governance with developed market relations (e.g., $\mathrm{Xi}$ Jinping's governance in China); 
c) ultranationalist ideas and ideas of religious fundamentalism.

Scholte proves that the only possibility of successful competition of liberal governance models with the above illiberal models is the use of the principles of diversity, reflexivity and practice. Scholte demonstrates the success of using these principles as part of the Building Global Democracy (BGD) program (2008-2014). Based on the ideas of Scholte, it is important for our study to draw the following two conclusions [3].

First, the understanding of the term "national interests" has changed, the meanings of which are determining in governance models and in the behaviour models of international management. At present, the country - nation - state connection is considered obsolete. The effectiveness of the democratic governance model is enhanced only if it competes with other democratic governance models around it. This competition is complementary. That is why the international practice recognizes that the "national interests" are the ones that go beyond the borders of the state. This is the promotion of democratic governance models at the global level.

Secondly, the Building Global Democracy (BGD) program has opened five innovations that are mandatory for modern democratic governance models. These innovations are: a) daring to transform democratic practices; b) reimagining the demos in global politics; c) reconstructing channels of democratic action; d) rethinking interconnections between global democracy and global justice; e) confronting structural power hierarchies in global politics [3].

The outcomes of the Building Global Democracy (BGD) program allow predicting that any change in governance model will encounter a number of major problems, including development, habit, power, resources, and uncertainty. A new governance model provides for a new model of international management behaviour. And vice versa, only international management with a new behaviour model is able to introduce a new governance model.

Scholte's study is important for Ukraine due to the fact that the ratification of the "Ukraine - European Union Association Agreement" [8] should provide, first of all, for changes in the state education system. Educational strategies that shape the moral qualities of international management should change [2]. The basis for choosing a governance model should be prepared. Only after that, based on the established values and moral qualities of international management, a liberal governance model should be selected.

The third idea. As we have already said, at present, the choice of any governance model should be based on the understanding that the management of "national interests" a priori implies the promotion and upholding of "national interests" beyond the state. For this reason, studying international management involves studying behaviour patterns at regional, national and global levels. Prato S. and Sonkin F. reveal the understanding of the terms "national" and "global" interests that has changed [4].

From the research by Prato and Sonkin it follows that the definition of a national idea comes to the fore based on which the meanings of the term "national interest" are formed. A clear definition of the meaning of the term "national interests" creates a restrictive framework for the behaviour of the "interested" parties, blocking the path of promoting corporate interests to the detriment of national interests. Hence, it is important for Ukraine to clearly articulate the meanings of "national interests", on the basis of which an assessment system for the behaviour patterns of international management will be formed.

Prato and Sonkin prove that at present, a new approach to the management system, called "multistakeholderism", is particularly popular. However, Ukrainian management must take into account that under the pretext of "multilateral interest" and democratic participation in decision-making at regional, national and global levels, the representatives of international corporations are introduced into the management system. As a result, national interests and their representation at the interna- tional level turn into the struggle of "stakeholders", which ultimately reduces state capacity. One illustrative example is the influence of the Soros Foundation in the CIS countries and the former Warsaw Pact. At first glance, this public organization, called the Open Society Institute, offers liberal values promoted by the United States. However, investigations in Hungary and Ukraine prove that in addition to philanthropy, the fund pursues certain economic interests. The Fund lobbies for the promotion of its representatives to the government entities, through which subsequently, it receives economic preferences. International management formed by the financial means of the fund works primarily for the interests of the fund, and only secondarily for the interests of the state.

Conclusions. Therefore, the authors examined the key democratic governance models that are used in the states of the European Union. As a result of the study, it was found that the formation of national interests and their representation at the global level depends primarily on the formation and sustainability of the moral qualities of international management, and not on the choice of a governance model. Any liberal governance model is determined primarily by the moral qualities of international management.

Beardsworth R. examined the importance of moral qualities in governance models and their transition to political responsibility. Beardsworth claims that in governance models, moral qualities manifest themselves in a specific way. They turn into moral responsibility and form an inextricable unity of moral and political behaviour in international relations [20].

Based on Beardsworth's study and the experience of practicing liberal governance models studied by us, we came to the following conclusion. The choice of a governance model in a global economy and democracy begins with the formation of moral qualities of international management. Without stable moral qualities, any governance model loses its effectiveness and does not contribute to the accumulation of public capital. In governance models, moral qualities turn into moral responsibility, which is the basis for the behaviour of international management when choosing a governance model and using this model in practice. In a governance model, moral qualities become political responsibility and ensure the formation, protection and promotion of national interests in the face of global threats and challenges.

\section{References.}

1. Lane, H., \& Maznevski, M. (2019). International Management Behavior: Global and Sustainable Leadership. Cambridge: Cambridge University Press. https://doi.org/10.1017/9781108637152. 2. Rudenko, S., Bazaluk, O., Tsvykh, V., \& Kalmuk, I. (2019). The Role of Philosophical Disciplines in Educational Strategies for Specialist Training in the Field of Public Administration. Naukovyi Visnyk Natsionalnoho Hirnychoho Universytetu, (3), 158-163. https://doi.org/10.29202/nvngu/2019-3/22. 3. Scholte, J. A. (2020). After Liberal Global Democracy: New Methodology for New Praxis. Fudan Journal of the Humanities and Social Sciences, (13), 67-92. https://doi.org/10.1007/ s40647-019-00265-3.

4. Prato, S., \& Sonkin, F. (2018). Editorial: Inequalities, Financialization, Technology: Sometimes the Nearest Exit is Behind You. Development, 61, 1-5. https://doi.org/10.1057/ s41301-019-00222-3.

5. FACTS. Income Inequality in the United States (2020). Retrieved from https://inequality.org/facts/income-inequality/. 6. Kyianytsia, L. (2019). The One Belt One Road Initiative as a New Silk Road: The (Potential) Place of Ukraine. Ukrainian Policymaker, 4, 21-26. https://doi.org/10.29202/up/4/3.

7. Vilkov, V. (2018). "Scientific Communism" and the Modern Political Science in Ukraine. Ukrainian Policymaker, 2, 48-55. https://doi.org/10.29202/up/2/7.

8. Association Agreement between Ukraine, of the one part, and the European Union, the European Atomic Energy Community and their Member States, of the other part (2015). Retrieved from https://zakon.rada.gov.ua/laws/show/984 011. 
9. Kuyper, J. (2016). Global Democracy. In N. Zalta Edward (Ed.). The Stanford Encyclopedia of Philosophy. Retrieved from https://plato.stanford.edu/entries/global-democracy/.

10. Fuchs, T.A. E. (2018). The Limits of European Integration Theories: Cyber-Development and the Future of the European Union. In E. Carayannis, D. Campbell, \& M. Efthymiopoulos (Eds.), Handbook of Cyber-Development, Cyber-Democracy, and Cyber-Defense. Cham: Springer. https://doi. org/10.1007/978-3-319-09069-6_62.

11. Soroka, L., \& Kurkova, K. (2019). Artificial Intelligence and Space Technologies: Legal, Ethical and Technological Issues. Advanced Space Law , 3, 131-139. https://doi.org/10.29202/ asl $/ 2019 / 3 / 11$.

12. Yuldashev, S. (2018). The Concept of Overcoming Corruption in the Management of the Space Industry in Ukraine. Advanced Space Law, 2, 112-117. https://doi.org/10.29202/ asl $/ 2018 / 2 / 12$.

13. Wu, G. (2017). Globalization against Democracy: A Political Economy of Capitalism after its Global Triumph. Cambridge: Cambridge University Press. https://doi.org/10.1017/9781108116077.

14. Zaring, D. (2019). The Globalized Governance of Finance. Cambridge: Cambridge University Press.

15. Blau, A. (2018). Cognitive corruption and deliberative democracy. Social Philosophy and Policy, 35(2), 198-220. https:// doi.org/10.1017/S0265052519000037.

16. Scholte, J. (Ed.) (2012). Building Global Democracy?: Civil Society and Accountable Global Governance. Cambridge: Cambridge University Press.

17. Little, A., \& Macdonald, K. (2013). Pathways to global democracy? Escaping the statist imaginary. Review of International Studies, 39(4), 789-813. https://doi.org/10.1017/ S0260210512000551.

18. Bazaluk, O. (2019). Plato's Traditions in Modern Educational Theories. Annals of the University of Craiova - Philosophy Series, 43(1/2019), 5-20.

19. Boettke, P.J., \& Candela, R.A. (2020). Productive specialization, peaceful cooperation and the problem of the predatory state: lessons from comparative historical political economy. Public Choice, 182, 331-352. https://doi.org/10.1007/ s11127-019-00657-9.

20. Beardsworth, R. (2015). From Moral to Political Responsibility in a Globalized Age. Ethics \& International Affairs, 29(1), 71-92. https://doi.org/10.1017/S0892679414000781.

\section{Моделі управління в епоху глобалізації: від моральної до політичної відповідальності}

\section{В. О. Філіпчук, Г. М. Малкіна, В. В. Колюх, I. I. Петренко}

Київський національний університет імені Тараса Шевченка, м. Київ, Україна, e-mail: v.filipchuk@icps.com.ua

Мета. Встановлення ролі та значення моральної відповідальності міжнародного менеджменту в моделях управління в умовах глобальної економіки й демократії.

Методика. Автори використовували структурнофункціональний, інституціональний, компаративний методи, а також методи синтезу та аналізу.

Результати. Автори розглянули і довели ключову тезу дослідження. Сучасний міжнародний менеджмент - це цілісна корпоративна культура управління. Базовою основою лідерських і професійних якостей сучасного міжнародного менеджменту є їх моральні якості. У демократичних моделях управління моральні якості менеджменту перетворюються в політичну відповідальність і забезпечують якість управління, зростання державного капіталу України, формування та просування національних інтересів в умовах глобальних загроз і викликів.

Наукова новизна. Автори довели, що визначальним актором моделі управління є міжнародний менеджмент, що володіє стійкими моральними якостями. Тільки в цьому випадку модель управління досягне найвищої ефективності та забезпечить зростання державного капіталу, а також просування національних інтересів в умовах глобальних загроз і викликів.

Практична значимість. Результати дослідження можуть бути використані для вдосконалення законодавчої бази, а також формування освітніх програм для навчання міжнародного менеджменту. Розглянутий досвід навчання міжнародного менеджменту, а також використання моральної відповідальності в моделях поведінки міжнародного менеджменту, забезпечить якість управління, зростання українського державного капіталу та просування національних інтересів у глобальній економіці й демократії.

Ключові слова: міжнародний менеджмент, моделі управління, моральна відповідальність, національні інтереси, державний капітал, глобальна економіка, глобальна демократія

\section{Модели управления в эпоху глобализации: от моральной к политической ответственности}

\section{В. А. Филипчук, А. Н. Малкина, В. В. Колюх, И. И. Петренко}

Киевский национальный университет имени Тараса Шевченко, г. Киев, Украина, e-mail: v.filipchuk@icps.com.ua

Цель. Установление роли и значения моральной ответственности международного менеджмента в моделях управления в условиях глобальной экономики и демократии.

Методика. Авторы использовали структурно-функциональный, институциональный, компаративный методы, а также методы синтеза и анализа.

Результаты. Авторы рассмотрели и доказали ключевой тезис исследования. Современный международный менеджмент - это целостная корпоративная культура управления. Базовой основой лидерских и профессиональных качеств современного международного менеджмента являются их моральные качества. В демократических моделях управления моральные качества менеджмента превращаются в политическую ответственность и обеспечивают качество управления, рост государственного капитала Украины, формирование и продвижение национальных интересов в условиях глобальных угроз и вызовов.

Научная новизна. Авторы доказали, что основоопределяющим актором модели управления является международный менеджмент, обладающий устойчивыми моральными качествами. Только в этом случае модель управления достигнет наивысшей эффективности и обеспечит рост государственного капитала, а также продвижение национальных интересов в условиях глобальных угроз и вызовов.

Практическая значимость. Результаты исследования могут быть использованы для совершенствования законодательной базы, а также формирования образовательных программ для обучения международного менеджмента. Рассмотренный опыт обучения международного менеджмента, а также использование моральной ответственности в моделях поведения международного менеджмента, обеспечит качество управления, рост украинского государственного капитала и продвижение национальных интересов в глобальной экономике и демократии.

Ключевые слова: международный менеджмент, модели управления, моральная ответственность, национальные интересы, государственный капитал, глобальная экономи$\kappa a$, глобальная демократия

Recommended for publication by V. P. Horbatenko, Doctor of Political Sciences. The manuscript was submitted 11.10.19. 